\section{TEMPORARY LOW-SKILLED MIGRANT WORKER PROGRAM IN KOREA: EMPLOYMENT PERMIT SCHEME}

\author{
Young-bum Park \\ Hansung University and HRD Korea \\ ybpark@hansung.ac.kr
}

Citation/Cómo citar este artículo: Young-bum, P. (2016). "Temporary Low-skilled Migrant Worker Program in Korea: Employment Permit Scheme". Arbor, 192 (777): a290. doi: http://dx.doi.org/10.3989/arbor.2016.777n1006

Received: September 12th, 2013. Accepted: October 31st, 2014.

ABSTRACT: In Korea low-skilled migrant workers increased drastically entering the 1990s. In 2003 'Employment Permit Scheme (EPS)' was introduced as social consensus formed that there should be legal channels to employ low-skilled migrant workers while providing proper treatment for them. In 2007 'TrainingWorking Scheme' under which migrant workers were treated trainees, not workers, was folded into the EPS. Different set of policies have been implemented for overseas Koreans reflecting the experiences of 36 years of Japanese colonial rule. Through implementing EPS, the government mainly aims to prevent corruption that might occur in the admission process of migrant workers and establish the employment order for migrant workers by suppressing undocumented stay and illegal employment. EPS has made a remarkable process in terms of achieving transparency and eradicating the corruption in the admission process. The number of undocumented migrants including low-skilled migrant workers reached its peak in 2002 at 289,239 then declined to 179,846 in March 2013. Among those, who entered Korea through EPS and 'Working Visit Scheme' accounts for $24.1 \%$ and $2.5 \%$ respectively. Even though the number of undocumented migrant workers has significantly reduced after the implementation of EPS, they are still a big part of migrant workers who are in the dead zone of labor rights and human rights. However, Korea's temporary low-skilled migrant worker program, EPS cannot be free from the criticism that it is a mere short-term manpower supply policy lacking comprehensive consideration of how to embrace low-skilled migrant workers as a migration policy or as a countermeasure to population changes.

KEYWORDS: Employment; Korea; Guest workers; low-skilled; overseas; permits.

\section{EL PROGRAMA PARA TRABAJADORES TEMPOREROS DE BAJA CUALIFICACIÓN INMIGRANTES EN COREA: PLAN DE PERMISOS DE TRABAJO}

Copyright: ( 92016 CSIC. This is an open-access article distributed under the terms of the Creative Commons Attribution-Non Commercial (by-nc) Spain 3.0 License

RESUMEN: El volumen de trabajadores inmigrantes de baja cualificación se incrementó drásticamente en Corea en los años noventa. El Employment Permit Scheme (EPS), se introdujo en este país en 2003 como un mecanismo legal para canalizar trabajadores de baja cualificación y asegurar su protección. En 2007 se incorpora a este programa el denominado "Training Working Scheme", para trabajadores en prácticas. También se han adoptado diversos programas para coreanos residentes en el exterior. A través de la implantación del EPS el gobierno coreano ha pretendido prevenir la potencial corrupción en el proceso de admisión de trabajadores migrantes y reducir la inmigración irregular y el empleo informal. La implantación del EPS ha constituido un mecanismo destacable en términos de lucha contra la corrupción y mejora de la transparencia. El número de trabajadores indocumentados alcanzó su máximo en Corea en 2002, y su volumen ha disminuido desde entonces. A pesar de que el número de trabajadores irregulares ha disminuido significativamente desde la implantación del EPS existe todavía en Corea un importante segmento de trabajadores extranjeros en situación irregular que ven vulnerados sus derechos humanos y laborales. La implantación de este programa no se ha producido sin la crítica de un buen número de actores que consideran que se trata de una mera política de suministro de trabajadores de baja cualificación, sin capacidad para abordar de una forma integral la gestión de la migración laboral y los retos del cambio demográfico.

PALABRAS CLAVE: Empleo; Corea; Trabajadores invitados; trabajadores inmigrantes de baja cualificación; coreanos en el exterior; permisos de trabajo. 
In Korea low-skilled migrant workers increased drastically entering the 1990s. In responding to need for low-skilled migrant workers, first Korea institutionalized the 'Industrial Trainee Scheme' under which migrant workers were treated trainees, not workers. The 'Industrial Trainee Scheme' was later changed to the 'Training-Working Scheme' which extended employment of qualified trainees for a certain period upon completion of training.

Strict migration controls made it increasingly difficult for Korean businesses to fill low-level jobs with legal, temporary migrant workers, and by the mid 1990s, more and more low-skilled migrant workers were overstaying visas and joining the workforce. They were able to easily find jobs and also paid large fees to job agencies at home and/or in Korea.

As low-skilled migrant workers were flowing into a country, the critical issue is whether it was a passing or structural phenomenon. One view is that the number of undesirable jobs increases as a free and democratic society becomes more affluent. Following this argument, Korea already reached this point in mid 1990s and bottom-end undesirable jobs had to be filled out largely by migrant foreign labor. Others see that labor shortage of low-skilled jobs can be solved by more efficient and intensive use of local labor. Not deciding which view was correct, Korea first introduced the Industrial Trainee System. However, the Asian financial crisis in December 1997 made Korea realize that some sectors of the Korean economy would not be viable. The unemployment rate jumped from 2.1 percent in October 1997 to 8.6 percent in 1999, leaving about two million people no jobs. However, only some workers wanted to take these undesirable jobs.

In 2003 'Employment Permit Scheme' was introduced as social consensus formed that there should be legal channels to employ low-skilled migrant workers while providing proper treatment for them. In 2007 'Training-Working Scheme' was folded into the 'Employment Permit Scheme.

Today, temporary migrant worker program in Korea, which is called the 'Employment Permit Scheme(EPS)', is divided into 'Ordinary EPS' for ordinary migrant workers (mostly non-overseas Koreans) and Special EPS for overseas Koreans. Different set of policies have been implemented for overseas Koreans reflecting the experiences of 36 years of Japanese colonial rule. Ordinary EPS and Special EPS grant 'Non-professional Employment' (E-9) and 'Working Visit' (H-2) visa respectively. Ordinary EPS is often called just EPS as Special
EPS is called 'Working Visit Scheme'. Since 2009 when global financial crisis hit Korea, no new migrant workers were brought under the 'Working Visit Scheme'.

This paper explains the main properties of Employment Permit Scheme, Korea's guest worker program and analyzes the outcomes of managing the system for more than 10 years and its limits. The remaining part of introduction provides Korea's immigration policy, the profile of Korea as a destination country and a picture of low-skilled migrant workers and their incorporation to Korean labor market. Section I explains the evolvement of Korea's temporary low-skilled migrant worker program was explained. In Section II and III, the main properties of Ordinary EPS and Working Visit Scheme (Special EPS) are described and compared, respectively. Ordinary EPS is the guest worker system known as EPS and Working Visit visa is issued to foreign nationals who are overseas Korean defined by the relevant law. Section IV evaluates outcomes of the EPS including preventing job loss for domestic workers and protection of migrant workers' rights and interest. Section $\mathrm{V}$ lists the limits and future tasks of the EPS.

Despite recent increases in its foreign population ${ }^{1}$, Korea is still a very homogeneous country. At the end of 2013, there were $1,576,000$ registered foreigners ${ }^{2}$, about three percent of Korea's 46 million people. As a country that places a high value on its homogeneity, it took more than 10 years for Korea to acknowledge the need for foreign labor to keep the "tiger" economy growing. Korea still maintains strict immigration policies with the desire to remain a purely Korean nation.

Chinese took the largest percent $(49.4 \%, 778,000$ persons) of the foreign population. 498,000 Chinese are overseas Koreans. Among The next largest nationalities were Americans (8.5\%) and Vietnamese (7.6\%). By visa type three visa types of Non-professional employment $(247,000)$, Working Visit $(240.000)$ and Overseas Koreans $(236,000)$ took 46 percent share. 'Working Visit' and 'Non-professional Employment' visa holders account for $98 \%$ of the all low-skilled migrant workers in Korea ${ }^{3}$. Korean labor market is very open for skilled migrants. There is neither labor market test, quotas, allowed occupation list, nor minimum salary requirement. However, the Korean law and policy concerning the settlement of skilled migrants is very rigid and the proportion of skilled foreign manpower is small compared to the low-skilled migrant workers ${ }^{4}$. As of the end of 2013, the number of 'skilled foreign manpower I' is 50,000. 'Foreign Language Instruction' (20,000 persons) made up the highest proportion, numbering 20,000, followed by Special Occupation and Arts \& Performances with 18,000 and 5,000 
workers, respectively. Most foreign language instructors came from English speaking countries such as the U.S., Canada and UK, and some were from China and Japan. Almost $70 \%$ of those in Arts \& Performances were from the Philippines. Foreign students increased very substantially from 25,000 in 2005 to 87,000 in 2010 . As of 2003 , the number of foreign students was 82,000 . Migrants accompanying their spouses rose 75,000 in 2005 to 142,000 in 2010, then to 151,000 in 2013.

From 2004 to May 2011, under the Ordinary EPS, 88.5\% of low-skilled migrant workers were brought into the manufacturing sector. As of March 2011, 91.1 $\%, 5.4 \%$, and $2.2 \%$ and $1.2 \%$ worked in manufacturing, agriculture and livestock, construction and fishery, respectively. The employment opportunities are very limited for service industry under 'Employment Permit Scheme'. Less than $0.1 \%$ had a job in the service industry (Yoo et al., 2011). There is no information about which industry undocumented workers who entered with 'Non-professional Employment' visa work for. As of March 2011, $50.1 \%, 41.3 \%$, and $6.4 \%$ and $1.8 \%$ of Working Visit visa holders worked in manufacturing, service, agriculture and livestock, and construction, respectively. According to the government internal data, $60 \%$ of workers under Ordinary EPS were employed in establishments with less than eleven employees. On the other hand, $75 \%$ of workers under Special EPS were employed in establishments with less than five employees, reflecting that many of them worked for small restaurants or were domestic helpers (Yoo et al., 2011). According to an ILO study (2014) ${ }^{5}$ which surveyed migrant workers from Vietnam, Thailand, Philippines, Sri Lanka and Nepal in 2013. 86\% of low-skilled Most migrants were males and under the age of 30 years. Most completed 9 years of basic education and stayed in Korea between 1 and 3 years. There were very few cases of migrant workers being paid below the set minimum wage. In most cases wages are between 1 million (1,000 US dollars) up to 1.75 million (1,750 US dollars) won per month. Most migrant workers sent money back home and some also had savings in Korea.

\section{HISTORY OF KOREA'S TEMPORARY LOW-SKILLED MIGRANT WORKER PROGRAM EVOLVEMENT}

It was since the early 1990s that the issues of importing low-skilled migrant workers have been actively discussed with the domestic labor market suffering from severe labor shortage problems. Before such discussions took place, low-skilled migrant workers started to enter Korea little by little since the late $1980 \mathrm{~s}^{6}$, in response to labor shortage in manufacturing small and medium-sized enterprises (SMEs), and they grew drastically in number entering the $1990 \mathrm{~s}^{7}$. As the labor shortage worsened, business communities demanded legitimate admission of low-skilled migrant workers $(\text { Seol, 1992) })^{8}$.

Mixed opinions existed on admission of foreign workers among the union and management and the government. Nevertheless, the government institutionalized 'Industrial Technology Training' in October 1991 by the directive of Ministry of Justice, which used to be operated according to the internal guidelines of the ministry, to allow entry of foreign industrial trainees up to 1 year only through foreign subsidiaries that are related to foreign investment, technology provision and equipment export.

As inflows of undocumented migrant workers increased and the labor shortage worsened in SMEs, since September 1992, the government allowed entry of foreign industrial trainees also through other routes than foreign subsidiaries in ten 'so-called 3-D (Dirty, Demanding and Dangerous)' manufacturing areas where the labor shortage was the severest.

Since 'Foreign Industrial Trainee Scheme' was implemented, due to systemic and administrative constraints, supervision of low-skilled migrant workers was thrown into disorder, which developed into social problems. As a consequence, the government made industrial trainees eligible for industrial accident compensation insurance and medical insurance and protected under the Labor Standards Act through articles concerning prohibition of forced labor and violence and observance of working hours. In addition, under the Occupational Safety and Health Act they could receive benefits from health and safety management regulations and health inspection. Also, as the Minimum Wage Act became applicable to them, their minimum training allowance rose to the minimum wage level.

Having seen various problems in the implementation of 'Foreign Industrial Trainee Scheme', the government tried to introduce 'Employment Permit Scheme' that permits legitimate employment of foreign workers, but its attempt did not go well, owing to different views of related ministries and opposition of trade organizations.

As the discussion on complementation of 'Foreign Industrial Trainee Scheme' continued, in 1998, the government introduced 'Training-Working Scheme' that extends employment of qualified trainees for 1 year, upon completion of training with their residential status changed from trainee to worker. Since 2002, it allowed two years of employment after one-year training. 
'Training-Working Scheme' had a feature of 'Employment Permit Scheme' where foreigners get a job as a worker during the two-year employment period. However, the implementation of 'Training-Working Scheme' did not achieve the expected outcomes either and had similar problems to 'Foreign Industrial Trainee Scheme'. One of the major purposes of introducing the 'TrainingWorking Scheme' was to reduce the number of undocumented migrant workers. The number of undocumented foreign population (most of them were estimated to work) was 99,537 in 1998, 189,595 in 2000 and 289,239 in $2002^{9}$, respectively, showing sharp increase. The number of migrant industrial trainees was only 51,852 who still did not become undocumented in $2002^{10}$. Moreover, it was subject to strong criticism, similar to what 'Foreign Industrial Trainee Scheme' received, from civic groups that the trainees were focusing on working rather than receiving training. In particular, as the Korean Supreme Court ruled that undocumented migrant workers are also defined as workers by the Labor Standards Act, some of them were able to receive greater legal protection and higher wages than legitimate industrial trainees with residential right ${ }^{11}$.

In 2003, which had been a decade since low-skilled migrant workers were actively introduced, social consensus formed that there should be legal channels to employ low-skilled migrant workers while providing proper treatment for them. As a result, 'Act on the Employment, etc. of Foreign Workers' was enacted and 'Employment Permit Scheme' started to be implemented in August. Until 2006, 'Training-Working Scheme' was implemented along with 'Employment Permit Scheme', but on January $1^{\text {st }} 2007$, the two schemes were integrated into 'Employment Permit Scheme'.
During the period of Japanese colonial rule, many Koreans had to migrate to foreign countries such as China, Russia and US, and thus in Korea, different set of policies have been implemented for overseas Koreans than for other types of lowskilled migrant workers. The Korean government opened up the door for overseas Koreans in phases by broadening the scope of Korean relatives and easing the minimum age limits.

In 2002, as 'Working Management' visa status was newly created, 'Working Management Scheme' was introduced, which allowed employment of overseas Koreans aged 40 or older with relatives in Korea, in the eight selected business areas within the service industry. In 2004, as the EPS was introduced, 'Working Management Scheme' started to run as the special case of EPS. The minimum age limit has been lowered to 25 , overseas Koreans in post-Soviet states were also welcomed, and twenty business areas were now open for them.

Following the criticism that under 'Working Management Scheme', employment procedures were too complicated, which required the migrant workers to change the visa type to 'Non-professional Working' once he/she got a job, it did not apply any quotas to the overseas Koreans with relatives in Korea although those without relatives in Korea were affected by quotas. In addition, employment opportunities were expanded to the manufacturing sector. In 2007, 'Working Management' visa was changed into 'Visit Working' visa (H-2), a newly created category, which provided eligible overseas Koreans with 5-year multiple entries.

Figure 1. Trend of Low-skilled Migrant Workers in Korea: 1993-2012

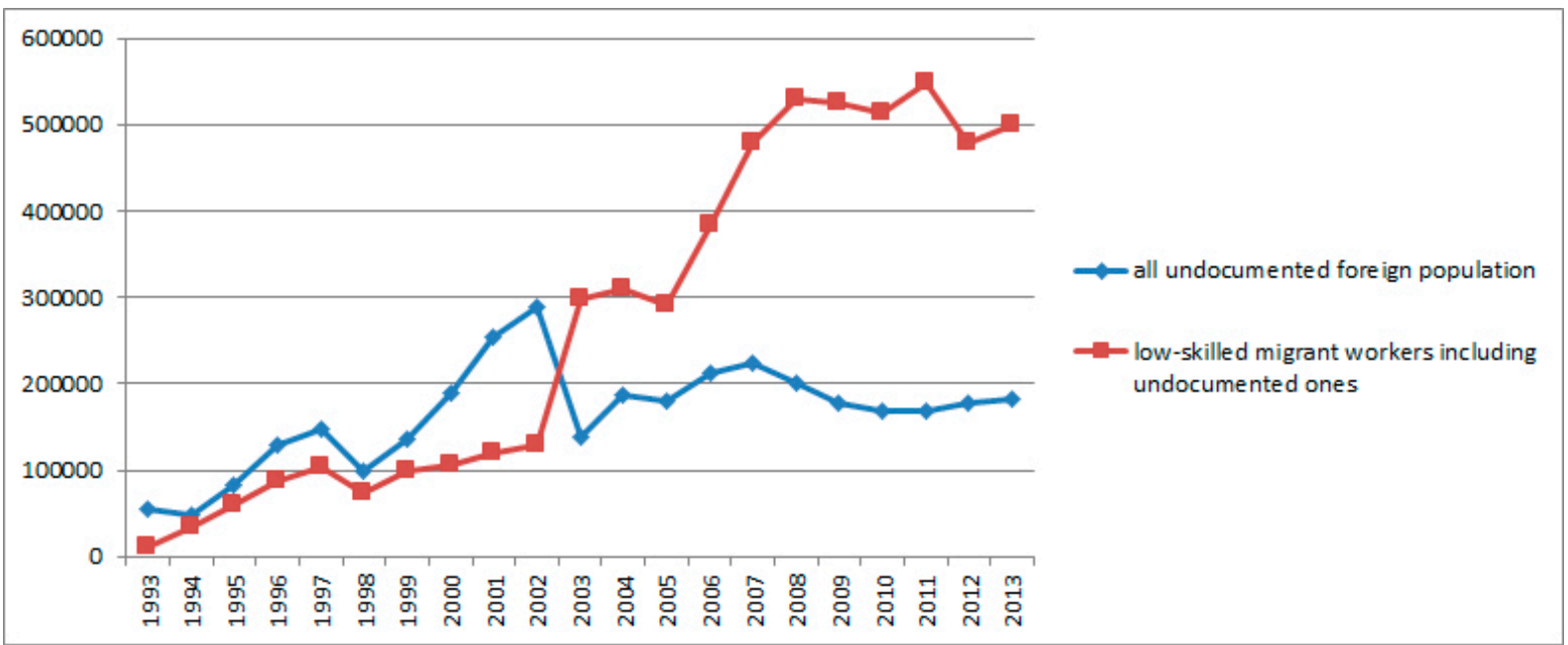

Source: Korea Immigration Service Homepage (http://www.immigration.go.kr) 


\section{MAIN PROPERTIES OF (ORDINARY) EMPLOYMENT PERMIT SCHEME}

In discussions on introducing the Employment Permit Scheme, the logic justification for the implementation of the scheme was suggested as follows. Through implementing EPS, the government could (1) prevent corruption that might occur in the admission process of migrant workers, (2) adhere to the principle of 'domestic labor market complementarities' in order to save jobs for domestic workers while allowing legal employment of migrant workers, (3) establish the employment order for migrant workers by suppressing undocumented stay and illegal employment, (4) prevent lowskilled foreign workers from settling down by allowing employment contract only up to 3 years at once and (5) guarantee equal treatment between migrant and do- mestic workers by protecting labor and human rights of migrant workers, (6) but needs to have the basic principle to prevent international competitiveness from deteriorating caused by the delay of structural reform of declining industries. (Yoo, Lee and Lee, 2003).

\section{Selection of Sending Countries and Migrant Wor- kers and Admission Procedures}

Selection of sending countries of low-skilled migrant workers is based on preference of employers, transparency and efficiency of the admission procedures of sending countries, guarantee of sending countries' governments concerning return of migrant workers to their home countries, worker's exit rate from the employed workplace, and diplomatic and economic relationships with sending countries.

Table 1. Comparison between Ordinary EPS and Special EPS (Working Visit Scheme)

\begin{tabular}{|c|c|c|}
\hline & Ordinary EPS & Special EPS \\
\hline $\begin{array}{l}\text { 1. Period of Stay } \\
\text { (Period of } \\
\text { Employment) }\end{array}$ & $\begin{array}{l}\text { - } 3 \text { years (could extended to } 4 \text { years and } 10 \\
\text { months) } \\
\text { - Entry with 'Non-professional Employment(E-9)' visa } \\
\text { and work for up to } 3 \text { years } \\
\text { <Re-employment is allowed upon employer's } \\
\text { request> }\end{array}$ & $\begin{array}{l}\text { - } 3 \text { years (could extended to } 4 \text { years and } 10 \\
\text { months) } \\
\text { - Entry with 'Working Visit'(H-2) visa and } \\
\text { work for up to } 3 \text { years } \\
\text { <Re-employment is allowed upon } \\
\text { employer's request> }\end{array}$ \\
\hline 2. Eligibility Criteria & $\begin{array}{l}\text { - Foreigners who are enrolled in the job applicant } \\
\text { pool through Korean language test and medical } \\
\text { checkup }\end{array}$ & $\begin{array}{l}\text { - Overseas Koreans who have relatives or a record } \\
\text { of family registry in Korea (quota not imposed) } \\
\text { - Overseas Koreans who do not have } \\
\text { relatives in Korea (quota imposed) }\end{array}$ \\
\hline 3. Business Areas & $\begin{array}{l}\text { - Business areas in manufacturing, construction, } \\
\text { service, agriculture, fishery and livestock } \\
\text { industries that are selected in Foreign Workforce } \\
\text { Policy Committee }\end{array}$ & $\begin{array}{l}\text { - Business areas that are open to Ordinary } \\
\text { EPS and some additional areas of service } \\
\text { industry }\end{array}$ \\
\hline $\begin{array}{l}\text { 4. Employment } \\
\text { Process }\end{array}$ & $\begin{array}{l}\text { - Korean proficiency test } \rightarrow \text { employment contract } \\
\rightarrow \text { entry with 'Non-professional Employment' visa } \\
\rightarrow \text { employment education } \\
\rightarrow \text { placement of workers } \\
\text { - restrictions on workplace changes }\end{array}$ & $\begin{array}{l}\text { - Entry with 'Working Visit' visa } \\
\rightarrow \text { employment education } \rightarrow \text { job seeking } \\
\text { assistance from job center } \\
\text { or free job searching } \rightarrow \text { employment } \\
\text { contract } \\
\text { - no restrictions on workplace changes }\end{array}$ \\
\hline $\begin{array}{l}\text { 5. Employer's Hiring } \\
\text { Process }\end{array}$ & $\begin{array}{l}\text { - Efforts to recruit domestic workers } \rightarrow \text { apply } \\
\text { for employment permission } \rightarrow \text { issuance of } \\
\text { employment permit } \rightarrow \text { employment contract } \\
\text { - obligation to report the start of employment not } \\
\text { imposed }\end{array}$ & $\begin{array}{l}\text { - Efforts to recruit domestic workers } \rightarrow \\
\text { issuance of verification document for special } \\
\text { employment } \\
\rightarrow \text { employment contract } \\
\text { - obligation to report the start of } \\
\text { employment imposed }\end{array}$ \\
\hline $\begin{array}{l}\text { 6. Employment Quota } \\
\text { per Enterprise }\end{array}$ & $\begin{array}{l}\text { - Quota for migrant workers by the size of } \\
\text { enterprise }\end{array}$ & $\begin{array}{l}\text { - Possibility to hire extra no. of overseas } \\
\text { Koreans, equivalent to the quota for } \\
\text { ordinary migrant workers } \\
\text { (except for construction and service industries) }\end{array}$ \\
\hline
\end{tabular}


Each year, the scale of admission of low-skilled migrant workers and its ceiling by business area are determined in the Foreign Workforce Policy Committee chaired by a government policy coordinator. The Committee consists of around 20 vice ministers from related ministries, including Ministry of Strategy and Finance and Ministry of Employment and Labor. In determining the target industries and quota for migrant workers, factors such as the business cycle of domestic economy, employment situation, surveys on foreign labor demands and manpower shortage rate, demands for substitute workers (consequent upon departure), opinions from relevant ministries are considered.

In order to maintain transparency of selection and admission procedures of low-skilled migrant workers, thereby preventing corruption, involvement of private entities is prohibited. Under the MoUs signed between the Korean government and the governments of the sending countries, eligibilities, selection methods, selecting agency, and terms and conditions are followed as agreed upon. As of 2012, the Korean government has signed MoUs with 15 governments of sending countries ${ }^{12}$.

Governments of sending countries (public organizations) select eligible workers (multiple of admission quota) using objective criteria such as Korean test score and career. Since August 2005, in order to prevent corruption and maintain objectivity in selection process, Korean proficiency tests take place under supervision of Human Resources Development Service of Korea (HRD Korea), and thus, only those who demonstrate certain level of Korean language proficiency could be registered in migrant job applicant pool.

Employers who want to hire low-skilled migrant workers send employment request to the regional public job center that provides public employment service, and if they fail to hire domestic workers for a certain period, several number of low-skilled migrant workers who meet the employment requirement are recommended from the migrant job applicant pool. Among those that are recommended, the employers can choose the most suitable candidates, for whom they receive employment permission ${ }^{13}$.

Public organizations including HRD Korea are in charge of practical affairs related to the administration of 'Employment Permit Scheme'. In regard to admission of low-skilled migrant workers, all the tasks that are related to sending countries, including cooperation with the sending countries and support for signing employment contracts are allocated to HRD Korea. As 'Foreign Industrial Trainee Scheme' was integrated into 'Employment Permit Scheme' in 2007, the implementing organizations ${ }^{14}$ for training under the former 'Foreign Industrial Trainee Scheme' were designated as agencies, which carry out various tasks to assist admission and supervision of low-skilled migrant workers, such as such as pre-employment education and post management of migrant workers, especially for the sake of employers.

\section{Industries That Are Subject to Employment Permit Scheme}

Enterprises with less than 300 regular workers or with less than 8 billion Korean won (about 8 million US dollar) of capital in manufacturing industry, service industry, agriculture, fishery and livestock industries are eligible to hire low-skilled migrant workers.

\section{Quota for Low-skilled Migrant Workers}

Employment quotas for low-skilled migrant workers are set ( 50 persons at most) according to the number of domestic workers covered by employment insurance system, and firms in non-Seoul (Korea's capital) area or those with severer labor shortage could hire additional workers, equivalent to $20 \%$ of the quota. Overseas Koreans hired through 'Working Visit Scheme' are not included in the quota of '(Ordinary) Employment Permit Scheme'.

\section{Rights of Low-skilled Migrant Workers and Restric- tion of the Rights}

The maximum duration of initial employment contract for a 'Non-professional Employment' visa holder is 3 years. The duration of contract could be decided or renewed upon agreement between both parties up to 3 years. Since 2009, the low skilled migrant workers whose three-year employment contracts are about to be expired could extend their period of employment once, up to 2 years without having to leave Korea. The government permits the extension of employment period up to 1 year and 10 months and therefore, lowskilled migrant workers with 'Non-professional Employment' visa could work up to 4 years and 10 months. In addition, since July $2^{\text {nd }} 2012$, those who worked without causing any problems in Korea for 4 years and 10 months could re-enter Korea in 3 months after returning to their home countries, and start working in the previous workplaces without taking Korean proficiency test or receiving pre-employment education.

Although it is the principle that low-skilled migrant workers with 'Non-professional Employment' visa 
work in the initial workplace, if there are appropriate reasons, such as when the working conditions are different from what was described in the employment contract, they could change their workplaces up to 3 times during the initial 3 year employment period, and twice during the 2 year re-employment period. However, if it is accepted and notified by the Minister of Employment and Labor that they can no longer work due to reasons for which workers are not liable, for example, shutdown of business, cancellation of employment permit and breach of working conditions regulations, the number of workplace changes does not count.

Low-skilled migrant workers with 'Non-professional Employment' visa could change their visa type to 'Residential(F-2)' or 'Special Occupation(E-7)' under limited conditions. The policy that allows the change of visa type to 'Residential(F-2)' has been in place since January 2008 , but it is widely argued that the policy has remained ineffective because the eligibility criteria were too strict. In 2011, there were only 3 people who could change the visa type to 'Residential (Skilled workers: F-2-6)' in this way. The policy that permits the change of visa type to 'Special Occupation(E-7)' was introduced in October 2011, thus its effectiveness is not known yet.

Low-skilled migrant worker are not allowed to bring their family members, but they could come as a worker separately even though they belong to the same family.

\section{Protection of Migrant Workers ${ }^{15}$}

Employers hiring migrant workers should sign up for 'Departure Guarantee Insurance' and 'Guarantee Insurance for Overdue Wages', within 15 days since the employment contracts came into force (except for 'Working Visit' visa holders in the construction industry). Among the four social insurances, health insurance, industrial accident compensation insurance are mandatory, employment insurance is optional and national pension varies by the home country of migrant workers.

Migrant workers legitimately employed by 'Employment Permit Scheme' and 'Working Visit Scheme' are subject to labor relations laws such as 'Labor Standards Act', 'Minimum Wage Act' and 'Occupational Safety and Health Act' and are also guaranteed of basic legal rights of labor, like domestic workers. According to the Article 22 of 'Act on the Employment, etc. of Foreign Workers', employers cannot unreasonably discriminate against migrant workers. National Labor Relations Commission, The National Human Rights Commission of Korea and the courts could provide remedies against employer's unlawful or unreason- able actions such as violation of employment contract or unfair dismissal.

According to 'Act on the Employment, etc. of Foreign Workers', councils on protection of migrant worker's rights and interests are established in public job centers under the regional offices of Ministry of Employment and Labor. In the councils, various issues that need to be addressed in regard to protecting rights and interests of migrant workers are discussed, including analysis of migrant worker's workplace changes, plans on the stable management of migrant workers, supportive measures for those who changed workplaces, ways to resolve disputes between employers and migrant workers, and supportive measures for stabilization of migrant workers' livelihoods and their employment.

\section{WORKING VISIT SCHEME (SPECIAL EPS)}

'Working Visit' $(\mathrm{H}-2)$ visa is issued to foreign nationals who are overseas Koreans, defined by 'Act on the Immigration and Legal Status of Overseas Koreans', aged 25 years and older, wanting to visit Korea or get a job in Korea. Their employment process consists of pre-employment education, job application, signing employment contract and alien registration in a sequence.

Overseas Koreans with 'Working Visit'(H-2) visa could get a job upon completion of the pre-employment education with assistance from public job centers. If employers are to hire overseas Koreans, they should have made efforts to hire domestic workers for a certain period. If they fail to employ domestic workers in spite of the attempts, they could hire overseas Koreans after receiving 'confirmation document' from the public job center and signing 'Standard Labor Contract'.

When overseas Koreans commence working or change workplaces, they only need to report it to the authority. Low-skilled migrant workers are required to report their new jobs to the Korea Immigration Service within 14 days after finding them. Restrictions on workplace changes do not apply to 'Working Visit' visa holders, unlike 'Non-professional Employment' visa holders, and wider range of business areas are open to them, except for a few that are closely related to the livelihoods of the working-class people such as retail sale of foods. The maximum period of one stay is 3 years for them, which could be extended up to another year and 10 months and, in this case, they have to submit the 'Certificate of Extension of Work Period' issued by public job center.

If an overseas worker aged under 55, whose work authorization of 4 years and 10 months has expired, vol- 
untarily leaves Korea, he/she will be able to comeback one year later $(6$ months for manufacturing firms in noncapital area and 3 months for agriculture, fishery and livestock industries) with renewed 'Working Visit' visa that permits another 4-year and 10-month stay in Korea.

Employers who hire foreign workers with 'Working Visit' visa should report to the public job centers within 10 days. In case the worker has been continuously working in the same workplace in agriculture, fishery and livestock industries for over 2 years, he/she can change the visa type to 'Overseas Korean (F-4)'.

Those who reported the start of their employment before August $1^{\text {st }} 2011$ can change the visa type to 'Overseas Korean (F-4)', if they worked in manufacturing industry, agriculture, fishery and livestock industries or as private nurses or housemaids for over 1 year in the same workplace, or over 6 months if qualifications are required in the related field.

Among 'Working Visit'(H-2) visa holders who are currently working, those whom the Minister of Justice acknowledges, considering the years of service, region of the employment, properties of the business area, status of labor shortage and job preference of the domestic workers, could obtain permanent residency upon their request. To be eligible, they should have stayed in Korea with 'Working Visit' visa for over 4 years. People who changed the visa type from 'Working Visit' to 'Overseas Korean' are not allowed to accompany their family members, including parents, spouses and children.

\section{GAP BETWEEN AIMS AND OUTCOMES OF THE EPS AND CONFLICTING POLICY CONSEQUENCES}

\section{Evaluation on preventing job loss for domestic workers}

From the perspective of economic theory, the influx of low-skilled migrant workers increases the supply of low-skilled workers in domestic labor market who are in a substitution relationship with low-skilled domestic workers. Therefore, this decreases low-skilled domestic workers' wage level and increases that of high-skilled Koreans, who are in a complementary relationship with migrant workers (Borjas, 1995).

According to numerous studies on the impacts of employment of migrant workers on domestic jobs during the implementation process of EPS, influx of migrant workers replaces temporary and daily workers to some extent and decreases the wage level and working conditions of domestic workers. This is probably happening especially in construction and service industries due to mass influx of overseas Koreans, but as the research outcomes vary depending on the subject and period of analysis and the data used, additional comparative research for decisive conclusions seems to be needed (Kim, 2009; Lee and Park, 2008; Yoo and Lee, 2009; Park, Seol and Lee, 2010; Yoo and Kim, 2010; Choi, 2011; Lee et al., 2011; Yoo et al., 2011). ${ }^{16}$

According to Yoo et al. (2011) the survey conducted on employers who hired migrant workers revealed employers believed that employment of migrant workers has complementary effects on domestic workers' jobs rather than harming them and does not have any effects on the wages and working conditions of domestic workers. However, in the case of construction industry, as much as $23.8 \%$ of employers believed overseas Korean workers extort jobs from domestic workers.

There is some controversy about whether the current selection methods of industries and quota for migrant workers are introducing an appropriate number of migrant workers in the appropriate sectors required by the Korean economy. First, the most troubling issue during the review process of Foreign Workforce Policy Committee is the lack of information in manpower shortage rate. Manpower shortage rate is suggested based on the Report on the Labor Demand Survey by the Ministry of Employment \& Labor, but there is a limit to fully understanding the demand for migrant workers due to excluding enterprises with five Korean employees or less then that use migrant workers most often, not reflecting characteristics of foreigner-employed workplaces (type of industry, weights by size etc.) in the sample design, and excluding agriculture, fishery and livestock industries from the research.

Second, whereas many people such as marriagebased immigrants, North Korean defectors and foreign students ${ }^{17}$, who could replace low-skilled migrant workers introduced by EPS, enter Korea, they are not considered in determining the quota under EPS (Lee et al., 2011; Park, Seol and Lee, 2010).

Third, as there is no institutional apparatus to suppress the demands for migrant workers through market mechanism, there is a potential for continued demand growth for them. Selection of industries that are open to migrant workers are done based on the labor shortage by industries and there are increasing number of requests each year for adding new industries on the list and for expanding the employment quota by workplace. Expanding the quota by industry or workplace makes it difficult to maintain 
the appropriate number of migrant workers as it increases the aggregate supply of migrant workers. If the government expands the size of non-professional migrant workforce continuously following the shortterm labor market situation, without considering the appropriateness of their size from the mid-long term perspective, it might distort the labor market.

Finally, to some extent test process of the labor market is not strictly followed at public job centers, although the current system has made it compulsory for employers to make efforts to hire domestic workers for a certain period of time. This is because social security receivers including self-supporting beneficiaries and the unemployed receiving unemployment benefits who find employment in small enterprises with poor working conditions that also employ migrant workers tend to be passive when seeking a job, and thus, find it difficult to get one.

\section{Satisfaction of Korean employers}

According to the satisfaction survey of employers who hired migrant workers through EPS (Yoo et al., 2011), most of the answers showed 'average' or 'slightly better than average' levels of satisfaction. Categories that showed the highest satisfaction level include services provided by public job centers and HRD Korea, post management of migrant workers, protecting migrant workers' human rights and decreasing the number of undocumented migrants. By contrast, the satisfaction level was relatively low in regard to documents required, administrative procedure, possibility of selecting migrant workers who fulfill the requirements of the workplace, and information on foreign job seekers provided by the public job center.

In the early implementation stage of EPS, there were growing concerns of taking considerable days on hiring migrant workers, due to the inefficiency of public institutions. Currently, under the EPS, it takes 75 days, on average, to receive request for foreign employment permit and assign them to workplaces. Considering that it takes about two to three months in Taiwan and Singapore where they introduce migrant workers through private job centers, the admission procedure in Korea is considered competitive.

Korean employers are relatively dissatisfied with the migrant workers' Korean skills and past work experiences. The biggest difficulties felt by employers include migrant workers' growing demands for higher wages and better working conditions under EPS compared to under the Foreign Industrial Train- ee Scheme, and problems hiring enough number of migrant workers that are needed.

EPS endeavors to guarantee employers the right to select migrant workers freely. However, the current EPS is inadequate, not being able to assist employers to find the workers with the right quality they are seeking ${ }^{18}$, as directory of job seekers are filled out in sending countries according only to the Korean proficiency test results. The biggest problem is the difficulty to check the skills or abilities the firms are demanding. Employers argue for institutional apparatus to verify the applicants' actual job competencies besides Korean skills.

\section{Evaluation on the Transparency of Admission and Administration Process of Migrant Workers and Pre- vention of Corruption}

If a migrant worker spends an excessive amount of money in the process of entering Korea, he/she would be more inclined to be engaged in employment for a longer period. EPS allows only public institutions the duties regarding selection and admission of migrant workers.

According to the survey conducted by the related institutions of the sending countries on the costs incurred for migrant workers to get a job in Korea through EPS, on average, they spent 927 US dollars on Korean proficiency test and flight tickets ${ }^{19}$. This is a huge drop from 3,509 US dollars, the average costs under the Foreign Industrial Trainee Scheme, or 4,862 US dollars, the average costs for illegal entrants (Yoo and Lee, 2001). This shows that EPS has made a remarkable process in terms of achieving transparency and eradicating the corruption in the admission process ${ }^{20}$.

In the assessment of EPS in 2007, 3rd anniversary of its implementation, Yoo mentioned that $61.6 \%$ of migrant workers responded their entry process was fair and transparent, $24.7 \%$ responded it was normal, and $10 \%$ responded it was unfair ${ }^{21}$.

However, even if the sending countries' government agencies or public institutions take the responsibility of the selection and admission process, there is no guarantee that the admission process will be transparent and cost less. This is because government officers who are in charge in the sending countries could also commit irregularities. In fact, there were some cases where public institutions of sending countries were involved in misconducts regarding the administration of the Korean proficiency test. It is crucial to prepare an institutional apparatus for continuous inspection and evaluation of the tasks carried out in the sending countries. 


\section{Prevention of Migrant Workers' Settlement and Their Undocumented Residence}

EPS was designed taking into account the necessity to prevent settlement of migrant workers which is reflected in its features that allow migrant workers to stay only within the limit of certain period while not allowing them to accompany their families. However, the key to preventing settlement of the migrant workers is to effectively prevent them from becoming undocumented migrant workers.

The number of undocumented migrants including low-skilled migrant workers reached its peak in 2002 at 289,239 then declined to 179,846 in March 2013. Among those, who entered Korea through EPS and 'Working Visit Scheme' accounts for $24.1 \%$ and $2.5 \%$ respectively. ${ }^{22}$ Among the 'Non-professional Employment' visa holders who came after the introduction of EPS, the proportion of undocumented migrants is estimated to be $16.9 \%$, as of March 2013. ${ }^{23}$ Compared to the past, when the 'Foreign Industrial Trainee Scheme' was being implemented, with the undocumented immigration rate staying around 60$70 \%$, it appears to have improved significantly. However, the proportion of undocumented migrants has been gradually increasing from $3.8 \%$ in $2007,5.5 \%$ in $2008,6.8 \%$ in $2009,12.0 \%$ in $2010,12.3 \%$ in 2011 then to $23.4 \%$ in 2012. Since the end of 2012, the time has come for many workers who entered Korea after the introduction of EPS to leave the country as their work authorization of 4 years and 10 months either have expired or are to expire soon, thus the issue would still have to be addressed.

\section{Protection of Migrant Workers' Rights and Interests}

According to Yoo et al. (2011), 7 years after the implementation of EPS, there is a wage gap between domestic workers and migrant workers, but considering the labor productivity, there is no wage discrimination.

In regard to overdue wages for migrant workers, the proportion of those who experienced delays in wage payments under the 'Foreign Industrial Trainee Scheme' was found to be $36.8 \%$ in 2001 (Yoo and Lee, 2001). However, the figure plunged in a survey conducted in 2007, showing only $9.0 \%$ of the respondents had received overdue wages. As of May 2011, those with overdue wages reported to the Ministry of Employment and Labor accounts for $1.1 \%$ of total migrant workers in Korea. Not all the migrant workers who are with overdue wages would report to the authority, but it seems clear that noticeable improvements have been made comparing when 'Foreign Industrial Trainee Scheme' had been implemented.
Even though the number of undocumented migrant workers has significantly reduced after the implementation of EPS, they are still a big part of migrant workers who are in the dead zone of labor rights and human rights. Rulings have been made by the court in Korea that undocumented migrants are subject to legal rights, as much as Korean workers are, but in reality, it is not easy for them to receive protection from the law.

It is necessary to consider policy measures to prevent illegal immigration from occurring. Some suggest that in particular, taking into account that it is impossible to block foreigners disguised as tourists from entering the country in the era of open economy, focusing the administrative power on the punishment of employers rather than on crackdown of the undocumented migrant workers would be more appropriate. One of the fundamental measures to reduce the number of undocumented migrants would be providing vocational training programs before they return to their home countries and providing programs that support starting up a business once they settle there. Official development assistance (ODA) funds could be used to finance the programs. (Park, Seol and Lee, 2010).

Although overseas Koreans are allowed to find a job by themselves, they find it difficult to do so because of lack of Korean skills, and so, they often get a job through unlicensed job brokers. ${ }^{24}$ This has led to various social problems such as brokerage commission charged by unregistered job brokers, employment in not-allowed business areas, and because of such unofficial employment channels, the workers are exposed to job insecurity and delay in wage payment. In particular, those without any relatives in Korea are more likely to struggle for livelihoods and this, in turn, might lead to other social problems. Therefore, effective employment support policies, including provision of more through pre-employment education are required for overseas Koreans.

\section{CONCLUDING REMARKS}

Korea's temporary low-skilled migrant worker program, EPS has its limits as follows. Firstly, it cannot be free from the criticism that it is a mere short-term manpower supply policy lacking comprehensive consideration of how to embrace low-skilled migrant workers as a migration policy or as a countermeasure to population changes. So far, the government tried to find ways to supply low-skilled migrant workers considering only the current labor market factors without close link between mid-long term expectation and the short term supply of labor. Dependency on low-skilled 
migrant workers of the firms that hire them is increasing due to the continued supplies of migrant workers meeting the industrial demands.

Secondly, in the past, low-skilled migrant workers were prohibited from re-employment for one year, but now if they spend some months back in home countries after fulfilling the employment contract, they could re-enter Korea and start working in the previous workplaces. This implies that although the government has continuously clarified the principle to rely on short-term rotations it has left the door open for a long-term stay. A long term stay is likely to raise their hopes for settlement and if they fail to settle legitimately, they might choose to do so illegally. There is a need to consider the utilization of low-skilled migrant workers in the framework of immigration policy ${ }^{25}$.

Thirdly, in case migrant workers are hired as cheap labor, firms might be satisfied with making use of such cheap workers, postponing the structural reforms, therefore in the long run, it would harm the competitiveness of the firms and the country (Park, Bohning and Abella, 1996). In the early days of admission of low-skilled migrant workers, heated discussions took place on the potential that migrant workers might hinder the sophistication of economic structure in Korea, but in the implementation of EPS, this aspect has not been considered enough while focusing on resolving SME's labor shortage problems. The government needs to consider introducing devices through which the increasing social costs of unregistered migrant workers are borne by the beneficiaries of their employment, i.e. employers. Employment of migrant workers should not impede the transition to high value-added economic structure by extending the life of declining industries that are uncompetitive.
Fouthly, 'Working Visit Scheme' could be understood from both the perspectives of overseas Korean policy and labor market policy. Approaching this from the standpoint of overseas Korean policy implies equalizing their treatment with local Koreans while approaching it from the standpoint of labor market policy implies maintaining restrictive stance on them as on ordinary low-skilled foreign workers. Influx of overseas Koreans will maintain the job competition between the marginalized group of local Koreans and overseas Koreans, centering around the service industry, unless the government takes a restrictive approach such as EPS. Whichever approach is taken to the overseas Korean issue, supports for their settlement and integration in labor market seem to be needed and thus, the government should make its stance on it clear.

Lastly, it is important to establish a system to systematically supervise low-skilled migrant workers who are employed in Korea. Admission quota and selection of business areas for migrant workers are under the jurisdiction of the Ministry of Employment and Labor while immigration control and affairs related to foreigner's entry and stay are under jurisdiction of the Ministry of Justice, and also there are other ministries and organizations involved. Therefore, establishment of efficient cooperative system among related ministries and organizations is important. In particular, close cooperation between the Ministry of Justice and the Ministry of Employment and Labor is important for preventing undocumented migrants from staying in Korea. As mentioned above, among low-skilled migrant workers who entered through EPS, the number of those whose visa expires is increasing, and also the number of other forms of unregistered migrants is rising. In order to prevent foreigners' illegal stay, active measures should be taken based on cooperation among ministries.

\section{NOTES}

1. The proportion to the total population increased from $1.53 \%$ in 2015 to $3.14 \%$ in 2013.

2. Foreigners who legally stay in Korea for 90 days or more are required to register with the authorities.

3. The rest is the 'Vessel Crew' which was 12,000 .

4. Low-skilled migrant workers account for about $90 \%$ of Korea's total migrant workers.

5. ILO Regional Office for Asia and the Pacific and ILO Korea Partnership, "Employment Permit System in Korea: Sur- vey of employers and migrant workers from 5 countries", Prepared for KNOMAD Workshop on Migration Cost, held in Pattaya in Thailnd from March 26 to 28, 2014, organized by the World Bank and ILO.

6. In 1980s migrant workers started to move into Korea due to domestic and international conditions, such as an economic boom experienced in Korea (between 1986 and 1989, the annual economic growth rates were more than $10 \%)$, and the aftermath of the Gulf War, which encouraged migrant workers to look for new destinations.
7. The number of undocumented migrant workers who entered with a short stay visa but ddi not leave after being employed rapidly increased from 5,007 in 1988 , to 18,402 in 1990 , then to 65,528 in 1992.

8. Meanwhile, the labor opposed the employers' insistence on admission of migrant workers, citing that importing foreign workers might deprive domestic workers of employment opportunities and serve as an obstacle to improvement of working conditions.

9. The numbers are as of December 31 of each year. 
10. The number of migrant industrial trainees who became undocumented was 76,337 as the end of 2002 .

11. Undocumented migrant workers are subject to the entire articles of Labor Standard Act, whereas industrial trainees are only subject to 8 articles. Some studies found that average income of undocumented migrant workers are higher than that of industrial trainees (Yoo et al., 2012, p 32).

12. The 15 countries include Indonesia, Nepal, Cambodia, Uzbekistan, Kyrgyzstan, Sri Lanka, Bangladesh, Philippines, Pakistan, Myanmar, East Timor, Vietnam, Thailand, Mongolia, and China.

13. Public job centers are in charge of receiving requests for extension of employment permit and re-employment, and reports on changes in employment of migrant workers.

14. These include Korea Federation of Small and Medium Business, Construction Association of Korea, National Agricultural Cooperative Federation and National Federation of Fisheries Cooperatives.

15. These protections also apply to migrant workers under "Working Visit Scheme".

16. $\operatorname{Kim}(2009)$ found that migrant workers are in a substitution relationship with low-skilled domestic workers who with middle school education or below. Lee and Park(2008) and Yoo and Lee(2009) found that there is a substitution effect between migrant workers and domestic workers in hotel and restaurant industries. Park et al.(2010) argued that as overseas Koreans who has shown a drastic increase in number since the implementation of 'Working Visit Scheme' has started working in construction industry and hotel and restaurant industries as daily workers, temporary and daily domestic workers have been replaced. They found that increasing share of manufacturing workers among the migrant workers has negative effects on the wage of domestic manufacturing workers, pointing out that the continued declining number of temporary and daily jobs shown in Economic Activity Census could be because of migrant workers. Yoo(2010) mentioned that domestic workers are more likely to lose jobs if the number of migrant worker in the same occupation and workplace increases, suggesting the substitutability between the employment of migrant workers and that of domestic workers in the same occupation. Choi(2011) found that1 percent increase in the labor supply with high school education or below caused by influx of migrant workers, is associated with a 0.2 percent drop in the wages of domestic workers with below high school education and expands the wage gap between those with below and over high school education by 0.3 percent. He argued that influx of low-skilled migrant workers expands the wage gaps by educational attainment, aggravating the polarization of labor market and that taking in 700,000 migrant workers would lower the wage growth rate of domestic workers with below high school education by $5-10$ percent. Lee et al.(2011) states that employment of migrant workers has significantly positive effects on profitability of firms and does not seem to cause any hindrance to the substitution by machinery or mechanization. According to Yoo et al.(2011), even though there are many industries where employment of migrant workers affects that of domestic workers, hardly any of them show enough evidence to suggest that they are negatively affected. However, the research has its limits since it was conducted on the overall domestic workers not those who were specifically in competition with migrant workers.

17. The number of foreign students coming to Korea has soared in recent years. There were only 7,288 foreign students in Korea as of the end of 2002, which increased to 88,408 by the end of 2011 . Foreign students do not have a legal right to work in Korea, but in fact, quite many of them do have a job in Korea. According to Statistics Korea, the economic participation rate of foreign students, as of June 2012 , is $20.1 \%$ and employment rate is $15.5 \%$.

18. Job seeker's information that is provided includes age, marital status, gender, height, weight, eyesight, color blindness, highest level of education attained and major, and photo.

19. HRD Korea. Survey on Entry Costs of Migrant Workers. 2011. Available from Internet: http://www.eps.go.kr/wem/ kh/index.jsp

20. HRD Korea, responsible for administering the Korean proficiency test, signing employment contract, supporting both entry and stay of migrant workers in the country, won the 2011 United Nations Public Service Award for "Admission
System That Supports Shared Growth of Migrant Workers and Employers" (Preventing and Combating Corruption). Its implications are huge in the sense that UN acknowledged the fairness, transparency and immediacy of the admission process of migrant workers that helps to resolve the labor shortage problems of SMEs while protecting migrant workers' rights.

21. Yoo, G. S. Evaluation of Implementation of Employment Permit Scheme for Three Years and Directions for Improvement", Prepared for the International Conference on Low-skilled Foreign Labor Policies in East Asia: Celebrating the 3rd Anniversary of Korea's Work Permit System, Korea University of Technology and Education, HRD Korea, Korea Labor Foundation, Korea International Migration Association.

22. Only a small proportion of migrant workers with 'Working Visit' visa become undocumented migrant workers largely because of relatively easy re-entry even when jobs are not available.

23. Figures from 2010 onwards were estimated from the figure in 2009 because the number of undocumented migrants whose stay was later legitimized through receiving 'Non-professional Employment' visa was not counted in the official figure.

24. Overseas Koreans do not need to receive employment permit and can sign an employment contract through free job search activities. Employers are also free to hire them without having to go through job centers and only need to report the start of employment to the authority. As a result, regulations that oblige employers to issue 'confirmation document for special employment' and report the start of employment are often not followed. However, the regulations are lacking legal force, levying only fines for not following them.

25. Abella, M., "Manpower Movements for Jobs Across Borders and National Government Responses: Global Trends", Prepared for 'FTA Human Resource Forum' held in Seoul on 22 January organized by Korea Research Institute for Vocational Education and Training and Hanyung Economic Daily. Korea has the fastest-growing ageing population among OECD countries, and Korea will reach the super-ageing society by 2026. 


\section{REFERENCES}

Borjas, G. J. (1995), The Economics of Benefits from Immigration. Journal of Economic Perspectives, 9, 2, pp. 3-22. http://dx.doi.org/10.1257/jep.9.2.3

Choi, K. S. (2011). Economic Effects of Influx of Foreign Workers and Migrants. KDI Policy Forum, 239.

Kim, J. H. (2009). Empirical Analysis on Economic Impact of Influx of Low Skilled Migrant Workers. Policy Research Series.

Lee, G. Y. and Park, S. J. (2008). Employment Structure of Foreign Workers and Their Influence. KLI Labor Review.

Lee, G. Y., Lee, S. R., Park, S. J. and Roh, Y. J. (2011). Empirical Analysis of Migrant Labor Market. Korea Labor Institute.

Park, Y. B., Bohning, R. and Abella, M. (1996). Study on Foreign Worker Policy. Korea Labor Institute.
Park, Y. B., Seol, D. H. and Lee, G. Y. (2010). Study on Mid-Long Term Directions for Improvement of Migrant Workers Policy. The Ministry of Employment and Labor of Korea.

Seol, D. H. (1992). Labor Market and Migrant Workers in Korea. The Economy and Society, 15.

Yoo, G. J. and Kim, J. H. (2010). Substitutability of Migrant Workers and Statistical Issues. Korea Development Institute.

Yoo, G. J. and Lee, G. Y. (2009). The Current Situation of Migrant Workers and Policy Agenda. Policy Research Series, pp. 2738.

Yoo, G. S. and Lee, G. Y. (2001). Employment of Foreign Workers and Policy Issues. Korea Labor Institute.
Yoo, G. S., Lee, J. H., and Lee, G. Y. (2003). International Comparison of Migrant Workers Policy. Korea Labor Institute and International Organization for Migration.

Yoo, G. S., Park, Y. B., Lee, H. C. and Seol, D. H. (2011). Evaluation of Implementation of Employment Permit Scheme and Measures for Improvement. Korea University of Technology and Education, The Ministry of Employment and Labor of Korea.

Yoo, G. S., Seol, D. H., Lee, G. Y. and Kim, S. H. (2012). A Study on Reform of Admission and Management System of Migrant Workers", Korea International Migration Association, The Ministry of Employment and Labor of Korea. 